\title{
Understanding cadets's evaluation of taste and wellbeing in one food menu from the Brazilian Air Force Academy through word association
}

\author{
Manoela Alves Pires ${ }^{1}$ and Marcos Henrique de Oliveira Barreto ${ }^{2}$
}

A questionnaire was conducted in the field with the cadets of the Brazilian Air Force Academy, and its main objective was to verify their perception of the food provided by the military organization, in order to understand which kinds of food were considered positive and negative foods for wellbeing and their daily physical performance, and how the food supplied affects their routine in any aspect. The research was carried out with 130 participants, through a questionnaire of unstructured qualitative analysis and word association technique. Participants were approached shortly after lunch, inside the mess hall. The results showed that the majority of cadets classified as positive or negative foods in terms of taste and not for their nutritional value. The cadets have also correlated food to physical and mental wellbeing and affirmed that a good meal directly affects their routine.

Keywords: Food, sensory thresholds, cognitive behavioral.

\section{Compreendendo a avaliação dos cadetes de um cardápio alimentar da Academia da Força Aérea Brasileira por meio de associação de palavras sobre sabor e bem-estar}

Foi realizado um questionário em campo com os cadetes da Academia da Força Aérea Brasileira tendo como principal objetivo verificar a percepção dos mesmos sobre os alimentos fornecidos pela organização, buscando compreender quais eram considerados alimentos positivos ou negativos para o bem estar e para o rendimento físico diário deles, e como consideravam que a alimentação fornecida poderia afetar a rotina deles em qualquer aspecto. A pesquisa foi realizada com 130 participantes, por meio de questionário e análise qualitativa não estruturada e técnica de associação de palavras. Os participantes foram abordados logo após o término do almoço, em uma única amostragem, dentro do próprio local (coletivo) de refeição. Os resultados mostraram que os cadetes definem qual alimento é positivo ou negativo apenas pelo paladar e não pelo valor nutricional, embora consigam correlacionar a alimentação ao bem-estar físico e mental e que uma boa refeição afeta diretamente a rotina deles.

Palavras-chave: Alimentos, limiar sensorial, cognitivo-comportamental.

${ }^{1}$ Brazilian Air Force Academy, Department of Education. Estrada de Aguaí, Jardim Bandeirantes, Pirassununga, São Paulo, Brazil. CEP 13635-900. Phone number: 19 3565-7295. E-mail : 


\section{INTRODUCTION}

Some researches of nutrition have advanced to demonstrate the direct influence of good nutrition on mood and personal wellbeing. According to Ryan and Deci[1], the psychological wellbeing, based on the currently most prominent conceptions, can be organized in two perspectives: one approaches the subjective state of happiness, and it is called subjective wellbeing, and another that investigates human potential and deals with psychological wellbeing. One of these studies affirmed that subjective wellbeing consists of four main components: pleasant emotions, negative emotions, global life judgments and satisfaction with specific domains ${ }^{22]}$.

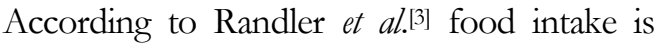
influenced by anxiety, disgust and negative emotions, considered subjective wellbeing. Food intake, in its turn, has a direct influence on one's life life quality, especially in stress, mood and daily disposition.

Another point is that the dietary habits of society have been changing in a negative way with the ingestion of nutrient-poor food, mainly in relation to vitamins and minerals, which have functions such as regulating the organism in terms of emotional state, which is important for the central nervous system ${ }^{[4]}$. Therefore, it is worth mentioning that a diet that is poor in essential nutrients can affect cognitive aspects, brain performance and sleep quality ${ }^{[2,4]}$.

Therefore, food intake can be influenced by subjective wellbeing as well as its nutritional composition can interfere with feelings and emotions, causing variations in brain functions.

The routine of the cadets from the Brazilian Air Force Academy (AFA) starts between 5:45 am and $7 \mathrm{am}$ - depending on whether they have flight activities or academic ones -, and is halted at $6 \mathrm{pm}$, after one or two hours of physic activity. From 7:30 pm to $10 \mathrm{pm}$ they have military instructions. During a 24 hour-period there are only four meals: breakfast, lunch, dinner and supper[5].

Nowadays, there are approximately between 600 and 650 cadets in AFA doing their graduation.
There are also more than 1,000 military personnel working in AFA. All the meals are prepared inside the institution to serve cadets and personnel, and its preparation is made by themselves. As both the cadets and the personnel undergo a rather arduous routine, planning the weekly menu is an activity of extreme importance that aims at technically programming meals that meet prerequisites, such as eating habits, supplying nutritional needs, attending hygienic-sanitary quality, and being directly linked to the posture of how each military faces their day.

According to Ares et al. ${ }^{\left[{ }^{[}\right]}$consumers strongly relate food to their physical and mental wellbeing. In this context, how is it possible to evaluate this relation in a Military Institution, that offers meals for a high number of people directly supplied for and by themselves?

In this context, the main objective of this research was to check the cadets' perception of meals offered by AFA and how it influenced their wellbeing during the academic routine, as well as the sensory evaluation of the food served.

\section{MATERIAL AND METHODS}

\section{Participants and Word Association Technique}

The research was carried out by a single questionnaire (Chart 1) using a word association technique, which is an unstructured qualitative analysis, commonly used in psychology and sociology methodologies [7]. The evaluation was done on a unique day, so only one menu was evaluated, because of the cadets' routine.

Chart 1. Questions asked to the cadets in the research

1.If you had to recommend positive foods that present an impact on the cadet's wellbeing, which 4 foods would you mention for the daily menu?

2. If you had to recommend negative foods that present an impact on the cadet's wellbeing, which 4 foods would you mention for the daily menu?

3. Write down the four first impressions, associations, or feelings that crossed your mind, which are related to how the food menu affect your wellbeing. 
According to Ares and Deliza[] this technique is increasingly being used in order to investigate the consumers' perception regarding foods. It is based on presenting stimulus to the interviewer requesting them to describe ideas that come freely to their mind. The researchers affirmed that when dealing with food the first idea that comes to the mind of the respondents may be the most relevant to exploit consumers' perception of a specific product, and spontaneous productions have fewer restrictions when imposed on interviews or closed questionnaires.

The research was approved by the Ethics in the Research Committee of the University of São Paulo, SP, Brazil (protocol number: 11344719.9.0000.5422), via Plataforma Brazil system. The test was conducted during lunch time and the participants were asked to complete a word association, based on the questions, considering the menu of the day, which was: salad, meat and potatoes, rice, beans, "escondidinho" (mix of mashed potatoes with shredded beef) juice and jam as dessert. A total of 130 cadets (both males and females), between 19-23 years old, answered the questions in which they should write down four words, descriptions, associations, thoughts or feelings that came to their mind.

\section{Data analysis}

The answers were evaluated and transcribed word by word and were analyzed qualitatively and quantitatively in the original language by the researchers. All the associations provided by the participants were considered. Categorization was made, the classification of terms with similar meanings were grouped in the same category, that was performed according to Rocha et al. [8], in an independent way by researchers that considered their personal interpretation of the meanings and synonyms of the words, and the final categories were reported reaching consensus. The frequency of categories (words) cited by participants was calculated by percentage and demonstrated graphically. The statistic of correspondence analysis (CA) chart was carried out in order to compare the answers of foods that were considered negative and positive by participants.

\section{RESULTS AND DISCUSSIONS}

The results of the first question, about positive foods are presented in Figure 1. The results showed a total of 393 citations, since some cadets answered only 1,2 or 3 words. The respondents considered the salad and chicken to be the best foods for wellbeing (17 and $16 \%$, respectively). The foods less cited were the lentil, hamburger, pork and feijoada (a stew of beans with pork beef, a typical dish in Brazil) as positive for wellbeing, representing $1 \%$ each one.

Figure 1. Number of citations from cadets about positive foods for wellbeing

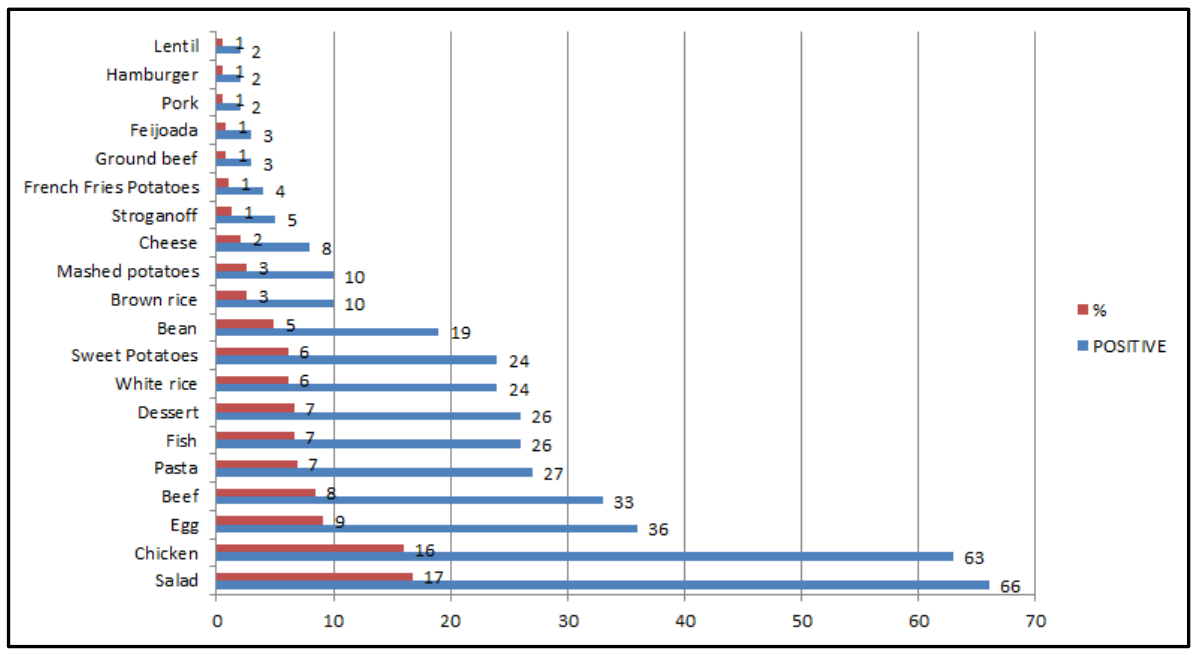


The numbers of citations of negative foods for the wellbeing are shown in Figure 2. Considering a total of 352 citations, the most cited by the interviewed cadets was fish $(26 \%)$. Following by fatty meat, with $10 \%$ of citations. The less cited ones were ground beef and lettuce. It is noted that the participants consider fish as negative for their wellbeing.

This result could be associated with different factors, such as food preparation that directly influences the taste. According to a research made in Alagoas State in Brazil, with 398 consumers, the majority of people preferred fried fish ${ }^{[9]}$. In the present study the menu evaluated did not present fish, but according to the serving history most fish offered by the Institution is cooked, suggesting that the cadets usually dislike it.
Another point is the Brazilian food culture. Souza et al.[10] evaluates the most popular foods consumed in Brazil and affirmed that "there is a basic food intake pattern in Brazil on rice, beans, coffee, bread and beef...", some regions of Brazil consume fish, but the consumption was considered lower. Sonoda and Shirota ${ }^{[11]}$ affirmed that Brazilian people do not have the consumption of fish as a habit, compared to other countries, fish occupying the fourth position in the type of animal protein consumed. Sartori and Amancio ${ }^{[12]}$ evaluated fish consumption in Brazil showing that fish purchases vary according to the country region, but they maintain that the consumption per capita in the country was still reduced when compared with Eastern countries.

Figure 2. Number of citations from cadets about negative foods for wellbeing

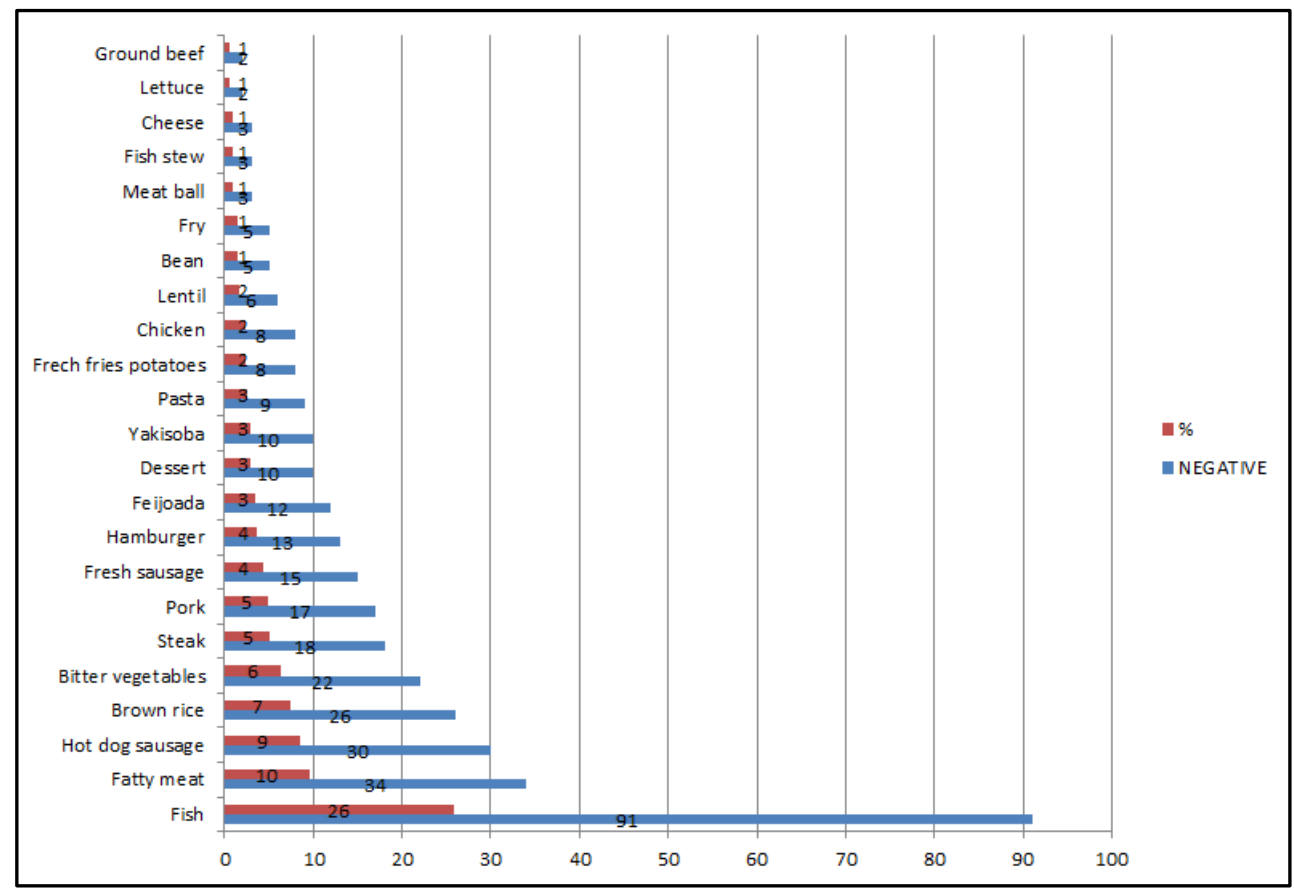

On the other hand, this result has demonstrated the cadets unknowledge about the health benefits of fish. Although the fishes types consumed in Brazil present low amounts of essential fatty acids, such as omega-3[13, 14], it is an excellent source of polyunsaturated fatty acids and protein ${ }^{[12,13]}$.
Some researches about healthy foods showed that preferences are associated with consumers' profile, such as socioeconomic or attitudinal[15, 16, 17].

Associating the answers of respondents in terms of positive and negative foods using correspondence analysis (CA) the Figure 3 separated 
the NEGATIVE and POSITIVE according to each cadet's evaluation.

It is noted that positive foods by cadets are directly associated with nutritional value (carbohydrates and protein) such as sweet potatoes, white rice, egg and chicken, but also with sensory and cognitive aspects, such as dessert. On the other hand, negative foods were related to cadets' cognitive and sensory acceptance, since they consider high nutritional value foods, such as vegetables, brown rice, fish, lentil and others to be negative to their wellbeing.

Figure 3. Answers association of positive and negative foods by correspondence analysis

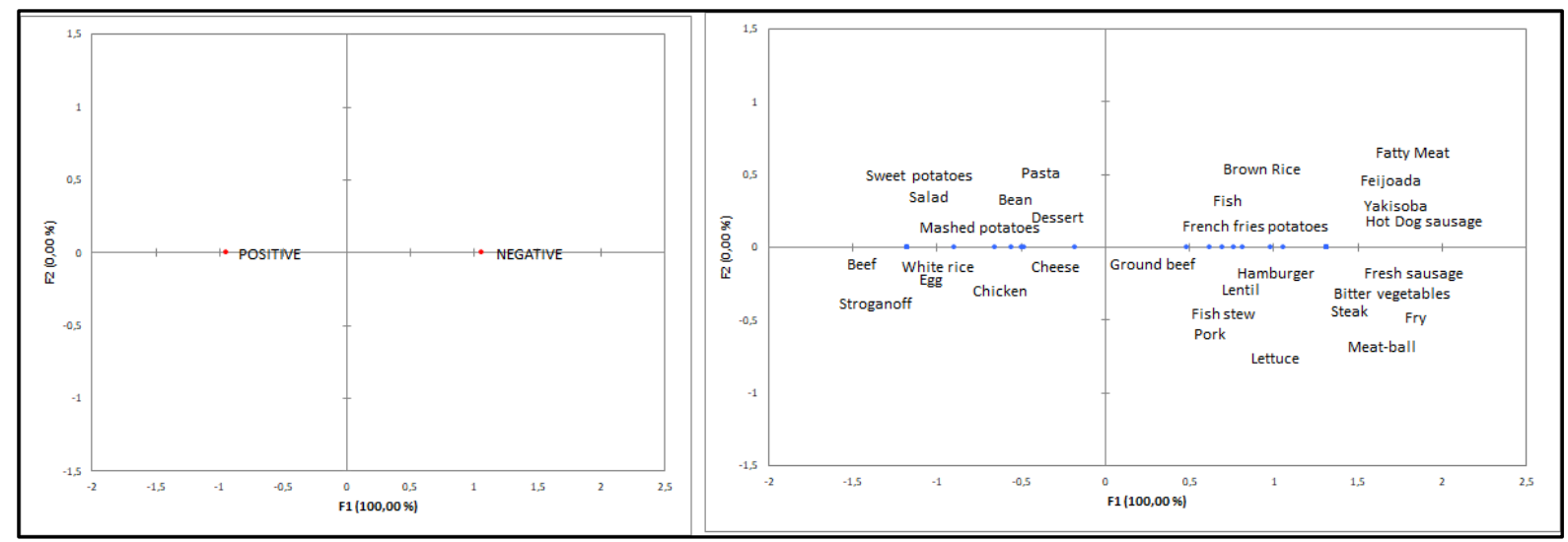

In spite of the fact that cadets associated the negative foods with sensory and cognitive aspects, Ares et al. [6] evaluated the consumers' opinion about foods and wellbeing in five countries, including Brazil, and noted that the effects of foods on wellbeing are related to manufacturing processes, nutritional composition and context of food consumption and not only with sensory characteristics. However, some foods cited in this present study as negative were also considered as harmful in the same research by Ares et al. ${ }^{[6]}$, such as foods high in fat (fatty meat), salt and sugar, meat products (hamburger, fresh sausage, hot dog sausage), junk food and fried food (French fry potatoes).

Regarding wellbeing, Ares et al. ${ }^{[6]}$ affirmed that food products (functional yogurts, ready-to-eat salads, local foods and traditional foods) were associated with positive emotions as calmness, health, happiness. Similar results were observed in this present study, according to the data of the third question (Figure 4), the majority of cadets cited positive emotions such as happiness, energy (18.6 and 14.2\%, respectively, total of 339 citations) when evaluating the daily menu food. 
Figure 4. Words cited by cadets about foods and wellbeing

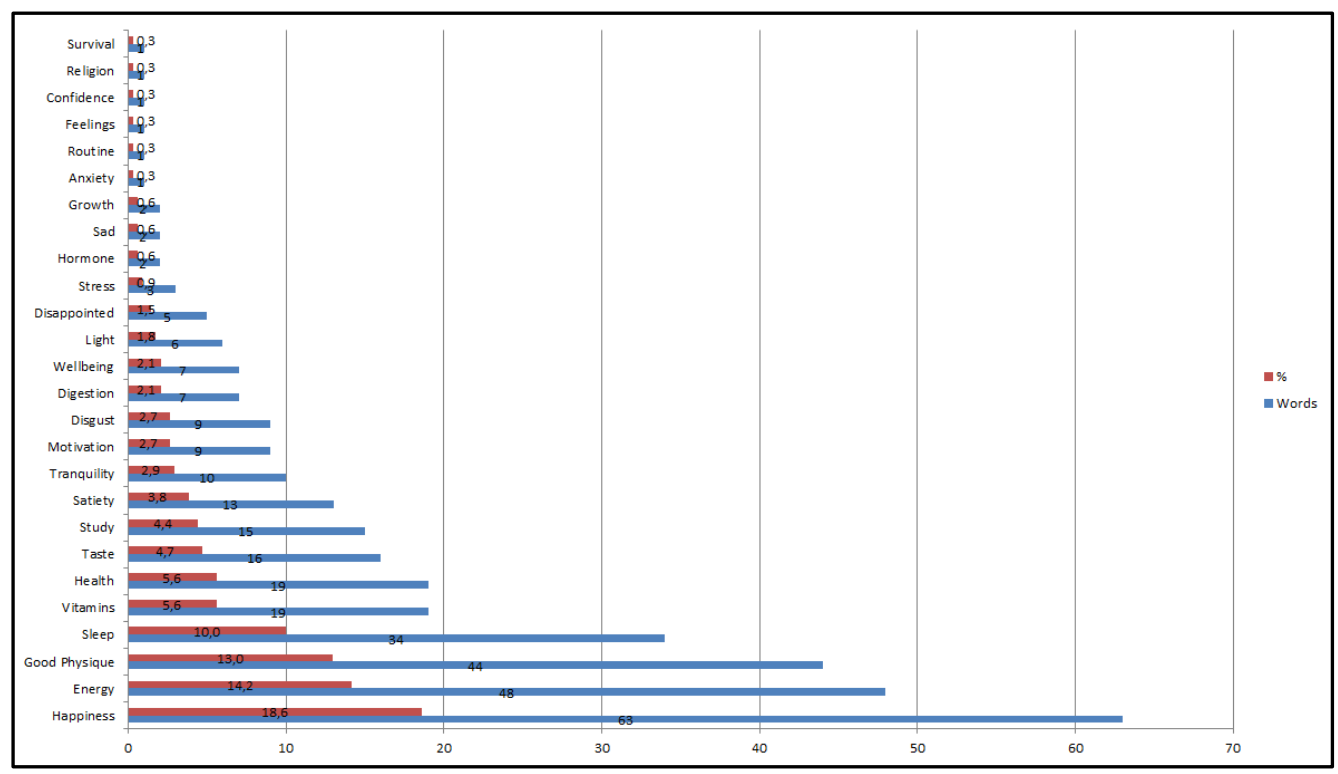

Good physique (physical activity) and good sleep presented an associated importance for cadets (13 and $10 \%$, respectively) in terms of their perception of food. Military training is known to demand a high physical performance, and sometimes, it influences sleep ${ }^{[18]}$, suggesting that the cadets cited these words based on their military routine ${ }^{[5]}$ (as mentioned in the introduction of the present study), and that it could affect concepts of emotions, wellbeing and food perception.

Even though the study made by Ares et al.[6] presented only positive emotions related to food products, in the present study negative emotions were cited by cadets: sad, stress, disappointment, disgust. It suggests, again, that the military routine can affect the individual's feelings.

According to Arkin and Dobrofsky ${ }^{[19]}$ some perceptions could be associated with the military basic training experience, that was confirmed by Delahaij and Dam ${ }^{20]}$ that affirmed that stressful situations related to military professionals, could be provide them with negative or positive feelings, as anxiety and confidence, and these were cited by cadets, as well as others as survival, religion and feelings (Figure 4).
Using the analogy for Figures 1,2 and 4 (positive, negative and wellbeing) it could be interpreted that salad and chicken brings happiness and energy. Chicken is a good source of protein ${ }^{[21]}$, and it is demonstrated that respondents presented knowledge of foods with higher source of protein.

The same goes for negative foods, fish and fatty meat could be interpreted as survival or feelings, suggesting that respondents were confused to cognitive/sensory aspects (fish) and knowledge that some foods could be harmful (fatty meat).

Based on the results, it can be observed that the cadets made a great diversity of correlations, reporting not only the most varied types of emotions and feelings, but also physical questions and thoughts related to the feeding provided by AFA, demonstrating that there is no standard definition for wellbeing. Similar results were found in the research conducted by Ares $e t$ al. ${ }^{[0]}$ in which it was commented: "consumers do not have a standard definition of wellbeing, and that different interpretations of what wellbeing is do exist".

The results of this research indicated that wellbeing is extremely important to the routine of anyone, so it has been realized that the more difficult one's day is, the better their meals should be. Based on 
the fact that the military routine can be more exhausting and it is directly related to food and meals served by the institution, the preparation and evaluation of the menu is an activity of extreme importance.

Santos, Ribeiro and Morais ${ }^{[2]}$ evaluated the menu of two military organizations in Brazil and affirmed that the menus should be reformulated to improve nutritional and sensorial aspects. Bueno and Bergamasco[23], state that emotions and sensations affect the decision making of an individual, and they are attributed to stimuli that are associated with mood states. In this context, it was noted that the cadets' military routine are stimuli associated with emotions and feelings that could directly affect the relation between the concepts of food and wellbeing.

\section{CONCLUSION}

According to the cadets' answers, most of them define positive or negative foods for their wellbeing based on taste and not on nutritional value. However, they perceived that food is of great importance for their routine, influencing their feelings and physical and mental disposition.

In this context, we could conclude that the foods served in the meals are of extreme importance to cadets in order to keep their physique and mental performance during the military routine. Results from the present work could contribute to the improvement of the meals from military institutions in order to contribute with military physique and their cognitive aspects, exploring better the sensory acceptance and nutritional aspects.

\section{ACKNOWLEDGEMENTS}

The authors are indebted to Brazilian Air Force (AFA) to the opportunity to carry out this research.

\section{REFERENCES}

[1] Ryan RM, Deci EL. On Happiness and Human Potentials: A Review of Research on Hedonic and Eudaimonic WellBeing. Annual Review of Psychology. 2001;3:141-166.
[2] Zhang S, Yang H, Singh L. Measuring quality of life: Economic, social, and subjective indicators. Social Indicators Research. 1997;40:189-216.

[3] Randler C, Desch IH, Otte im Kampe V, WüstAckermann P, Wilde M, Prokop P. Anxiety, disgust and negative emotions influence food intake in humans. International Journal of Gastronomy and Food Science. 2017;7:11-15.

[4] Mann J, Truswell AS. Essentials of human nutrition. United Kingdom: Oxford University Press; 2017.

[5] Brasil \& Força Aérea Brasileira. Norma Padrão de Ação: Rotina e Formaturas do Corpo de Cadetes da Aeronáutica. Portaria AFA no 244 de 27 de novembro de 2018.

[6] Ares G, de Saldamando L, Giménez A, Claret A, Cunha LM, Guerrero L, de Moura AP, Oliveira DCR, Symoneaux R, Deliza R. Consumers' associations with wellbeing in a food-related context: A cross-cultural study. Food Quality and Preference. 2015;40:304-315.

[7] Ares G, Deliza R. Identifying important package features of milk desserts using free listing and word association. Food Quality and Preference. 2010;21(6):621-628.

[8] Rocha YJP, Lapa-Guimarães J, de Noronha RLF, Trindade MA. Evaluation of consumers' perception regarding frankfurter sausages with different healthiness attributes. Journal of Sensory Studies. 2018;33(6):1-14.

[9] Santos EL, Garcia PHM, Soares EC, Machado SS, Silva JM, Oliveira WDS. Perfil do consumo de peixes na cidade de Maceió, Alagoas. Revista Científica de Produção Animal. 2016;18(1):45-54.

[10] Souza AM, Pereira RA, Yokoo EM, Levy RB, Shichieri R. Alimentos mais consumidos no Brasil: Inquérito Nacional de Alimentação 2008-2009. Revista de Saúde Pública. 2013;47(1):190-199.

[11] Sonoda DY, Shirota R. Consumo de pescado no Brasil fica abaixo da média internacional. Visão agrícola. 2012; $8(11): 145-147$.

[12] Sartori AG de O, Amancio RD. Fish: nutritional relevance and consumption in Brazil. Segurança Alimentar e Nutricional. 2015;19(2):83-93.

[13] Scherr C, Gagliardi ACM, Miname MH, Santos RD. Concentração de Ácidos Graxos e Colesterol de Peixes Habitualmente Consumidos no Brasil. Arquivos Brasileiros de Cardiologia. 2015;104(2):152-158. 
[14] Simopoulos AP. Omega-6/Omega-3 Essential Fatty Acid Ratio and Chronic Diseases. Food Reviews International. 2004;20(1):77-90.

[15] Ares G, Gámbaro A. Influence of gender, age and motives underlying food choice on perceived healthiness and willingness to try functional foods. Appetite. 2007;49(1):148158.

[16] Ares G, Giménez A, Gámbaro A. Understanding consumers' perception of conventional and functional yogurts using word association and hard laddering. Food Quality Preference. 2008;19(7):636-643.

[17] Van Wezemael L, Caputo V, Nayga RM, Chryssochoidis G, Verbeke W. European consumer preferences for beef with nutrition and health claims: A multi-country investigation using discrete choice experiments. Food Policy. 2014;44:167-176.

[18] Rosendal L, Langberg H, Skov-Jensen A, Kjaer M. Incidence of injury and physical performance adaptations during military training. Clinical Journal of Sport Medicine. 2003;13(3):157-163.

[19] Arkin W, Dobrofsky LR. Military Socialization and Masculinity. Journal of Social Issues. 1978;34(1):151-168.

[20] Delahaij R, Dam KV. Coping with acute stress in the military: The influence of coping style, coping self-efficacy and appraisal emotions. Personality and Individual Differences. 2017;119:13-18.

[21] Tondrá F. Handbook meat processing. USA: WileyBlackwell Editor; 2010.

[22] Santos AS, Ribeiro DMA, Morais PMO. Avaliação qualitativa do cardápio de uma unidade de alimentação e nutrição de área militar em Belém-PA. In: Resumos do III Congresso de Educação em Saúde da Amazônia; 20141214 novembro; Pará, Belém: COESA; 2014.

[23] Bueno VF, Bergamasco NHP. Efeito da associação de sabor e música sobre o estado de ânimo de crianças. Estudos de Psicologia. 2008;25(3):385-393. 